Section Editor: W. A. STEINER

Note: It is the purpose of this section of the IJLL to direct the attention of readers to articles and periodical titles which may be thought to be of particular interest to them. Information concerning some of these items will be summarized, abstracted or noted at greater length and in greater detail, some more briefly and in less detail. In some cases, references only will be given. While, in general, recent articles will form the subject matter of this section, references and notations to articles previously published might be included if they are still considered useful and topical.

\title{
Retrospective Periodical Articles Noted
}

-In this regard, attention is drawn to articles on individual law libraries which have appeared in the LAw Librarian, the bulletin of the British and Irish Association of Law Librarians. To abstract them would be repetitious and, therefore, serve very little point, but reference should be made to them. The libraries concerned are : Liverpool University Law Library (vol. 1, 1970, pp. 3-4, by D.J. Way); The Law Society Library (vol. 1, 1970, pp. 15-19, by F.P. Richardson); the Library of the House of Commons (vol. 1, 1970, pp. 31-34, by D. Menhennet); the Signet Library, Edinburgh (vol. 2, 1971, pp. 3-5, 15, by G.H. Ballantyne); Southampton University Library: the Law Collection and the Ford Collection of Parliamentary Papers (vol. 2, 1971, pp. 19-20, by J.L.M. Hoyle and D.M. Marshallsay); the Legal Section of the Foreign and Commonwealth Office Library (vol. 3, 1972, p. 3, by J.H. Wormald) ; the Harding Law Library, University of Birmingham (vol. 3, 1972, pp. 19-22, by D.M. Blake); the Home Office Library (vol. 3, 1972, pp. 36-39, by D.B. Gibson); King's Inns Library, Dublin (vol. 4, 1973, pp. 3-4, by M.J. Neylon); University of Edinburgh: Law Library and Library of the Centre of European Governmental Studies (vol. 4, 1973, pp. 19-20, by E.R.S. Fifoot) ; United Nations Library, Geneva: legal section (vol. 4, 1973, pp. 35-36, by B.I. Ross) ; Gray's Inn Library (vol. 5, 1974, pp. 3-5, by P.C. Beddingham); Bristol University Law Library (vol. 5, 1974, pp. 19-20, 29, by S. Paget) ; Law Commission Library (vol. 6, 1975, pp. 3-4, by D. Raistrick) ; Nottingham University Law Library (vol. 6, 1975, pp. 19-21, by R.G. Logan); the Radzinowicz Library of Criminology, Cambridge (vol. 7, 1976, pp. 3-6, by R. Perry); the Bodleian Law Library, 
Oxford (vol. 7, 1976, pp. 19-21, by S.A. Lush) ; the Codrington Library, All Souls College, Oxford (vol. 7, 1976, pp. 36-38, by J.S.G. Simmons); Lincoln's Inn Library (vol. 8, 1977, pp. 3-4, by R. Walker); Durham University Library (vol. 8, 1977, pp. 19-22, by S.M. Doyle); Law Libraries in the University of Wales (vol. 8, 1977, pp. 35-38, by J. Dane, E. Nash and D.L. Jones); University of Kent at Canterbury Library (vol. 9, 1978, pp. 19-22, by J. Jeffries); University of Exeter Law Library (vol. 9, 1978, pp. 35-36, by J. Cartwright) ; University College London (vol. 10, 1979, pp. 3-7, by B. Tearle) ; the Supreme Court Library (vol. 10, 1979, pp. 13-16, by K.W. Best).

\section{Recent Periodical Articles and Titles Noted}

-The Report of the Royal Commission on Legal Services in England, Wales and Northern Ireland was published in October 1979. The Report (Cmnd 7648) is the first of its kind and has more than 1,600 pages in two volumes, obtainable from HMSO at $£ 12.00$ for vol. 1 and $£ 11.00$ for vol. 2. The first installment of a two-part summary of this important study has appeared in the Commonwealth Law Bulletin, October 1979 issue, pp. 1266-1315.

An international conference to review the Report of the Royal Commission on Legal Services is organized by the British Journal on Law and Society in conjunction with the Faculty of Law at University College, Cardiff, March 21-23, 1980. The conference will be concerned with theoretical and substantive issues on both a national and comparative basis. Further information on the conference is obtainable from: Richard Lewis, Faculty of Law, University College, P.O.B. 78, Cardiff CF1 1XL, Wales, United Kingdom.

- The International Journal of the Sociology of Law has published its November 1979 number (vol. 7 no. 4) as a special issue devoted to the topic of "The Legal Profession". Following an introductory article by Editor Maureen CAIN on "The General Practice Lawyer and the Client: Towards a Radical Conception", there are other contributions on lawyers in Brazil, Venezuela, Papua New Guinea and Australia.

Though this journal commenced publication in 1973 and is now in its seventh volume, it may not be widely known among lawyers and law librarians because its editors are predominantly sociologists. Nevertheless it should be of interest to lawyers as it contains articles on a variety of socio-legal topics (for example, a recent issue includes articles on the corruptive behavior of multinational corporations and on the use of sociology in police work). Its book reviews are equally interesting. Each issue is about $80-100$ pages long. Published quarterly by the Academic Press Inc. (London) Ltd., 24-28 Oval Road, London NW17DX, England, 
it is distributed at the usual discriminatory subscription rate prevalent among so many altruistically misguided scholarly periodicals: US $\$ 42$ for institutions abroad, $£ 15.90$ for institutions in Britain, and $£ 9.60$ for individual subscribers. North and South American subscribers should write to Academic Press Inc., 111 Fifth Avenue, New York, New York 10003, USA.

-The bound volume of the 1978 Annual Survey of American Law, recently published, includes in its Supplement, pp. 55-159, a useful, practitioner-oriented bibliography of international law with brief annotations, by Professor Julius J. MARKE of New York University School of Law. Appearing in the bound volume of the Annual Practice of American Law 1978, the 104 page bibliography lists some 1,000 currently relevant treatises, monographs, periodicals, and other serial works published predominantly in the English language (though some reference is also made to French and German language materials) and dealing with international law in the widest sense of that term. The subject coverage is extraordinarily broad and comprehensive. In addition to standard international law materials, it includes copious references to books on international trade and economic laws, international organizations, comparative law, and the laws of countries other than the United States.

The bibliography is arranged in two parts. The first part lists bibliographies, dictionaries, periodicals, yearbooks, and other general reference works. It is a useful checklist not only for lawyers but also for law librarians interested in the development of their library collections. However, by far the greatest value of the bibliography is to be found in the 85 page long second part where entries to materials are arranged alphabetically under seventy-two subject headings. Considerable imaginative skill is used in the selection of subjects. The author of the bibliography does not confine himself to such established categories as international and comparative law. His aim is to expedite research by grouping entries under convenient keywords of modern usage, and he succeeds admirably in this respect. Thus the bibliography includes such subject headings as, for example, atomic energy, branches and subsidiaries, continental shelf, customs, East-West trade, international commercial arbitration, leasing, propaganda, transfer of technology, and women.

Each entry contains complete bibliographic information. In addition, many entries have brief descriptive annotations.

Though aimed at the United States attorney, this bibliography should also be useful to lawyers and law librarians in other countries as a source of information about English language publications in the broad and ever expanding field of the international practice of law.

A footnote to the bibliography states that a "revised, updated, and more fully annotated edition, with an author index, will be published in late 1979 by the W.S. Hein Company of Buffalo, N.Y." 
- Since 1976, when Dr. Ralph LANSKY of the Max-Planck-Institute in Hamburg reported to the IALL Roundtable in Lausanne on his project of preparing a Handbuch der Bibliographien zum Recht der Entwicklungsländer/Handbook of Bibliographies on Law in the Developing Countries, considerable progress has been made, including a preliminary edition issued in 1977. After some intensive weeks of recent work in various British libraries in London, Dr. LANSKY is now preparing the final manuscript for publication in 1980 by Klostermann in Frankfurt. The Handbuch will have ca. 700 pages and will comprise some 1,200 bibliographies with brief annotations, a detailed index in German and English, and a critical evaluation of the state of legal bibliography in the developing countries. The Deutsche Forschungsgemeinschaft will provide a subsidy to help cover part of the costs of publication.

- The International Encyclopedia of Comparative Law, edited at the Max-Planck-Institute for Foreign and International Private Law in Hamburg, is a unique venture in the annals of world-wide cooperation of legal scholars. Conceived in the 1960's, it began issuing its first installments in 1971 and has now reached a stage where more than one third of the planned contents of the Encyclopedia is available in published form. The January 1980 issue of the American Journal of Comparative Law will bring "The International Encyclopedia of Comparative Law: A Bibliographical Status Report" by Adolf SPRUDZS of the University of Chicago Law School, providing up-to-date information on this very important compendium of comparative law as well as a complete bibliography of all parts published as of July 31, 1979.

-Gloria WESTFALL, Foreign Documents Librarian at the Indiana University Library in Bloomington, Ind., is putting the finishing touches on a manuscript for the first book-length treatment in English of French government documents. Under the title French Official Publications it will be issued by Pergamon Press in 1980. This new reference guide will provide information on the acquisition of French government documents, their distribution, bibliographic control and legal access, as well as useful hints and advice to librarians in building a collection of French official publications and retrieving information from them.

-Beginning in November 1979 the European Free Trade Association (EFTA) started publishing a newsletter as a supplement to the EFTA Bulletin. The Newsletter, called EFTA REPORTER, will give readers up-to-date information about EFTA activities, current and coming events, etc. It will be published in four languages-English, French, German and Swedish. In 1980 the EFTA Bulletin will appear every two months, whereas EFTA REPORTER will be distributed more frequently. It can be obtained free of charge from the EFTA Press and Information Service, 9-11, rue de Varembé, 1211 Geneva 20, Switzerland. 
-Among NEW SERIALS noticed and too numerous to list here, a few are selected for our readers' information:

European Human Rights Reports. Quarterly. Vol. 1-January, 1979London: European Law Centre Ltd., 1979-Annual subscription: $\$ 135.00$.

Nigerian Annual of International Law. Vol. 1 (1976). Editor: T.O. Elias. Yaba, Nigeria: Oxford University Press, Nigerian Society of International Law and Nigerian Institute of International Affairs, 1979. Pp. 315.

Rivista italiana di medicina legale. Dottrina, casistica, ricerce sperimentale, giurisprudenza e legislazione. Pubblicazione trimestrale. Anno 1-1979Milano: Giuffrè, 1979-Annual subscription: 1979-Lire 16,000 (esteroLire 25,000); 1979/1980-Lire 24,000 (estero-Lire 40,000).

Tijdschrift voor Familie—en Jeugdrecht. Vol. 1-Januari 1979-Zwolle: W.E.J. Tjeenk Willink, 1979-Six times a year. Annual subscription for 1980 : Dfl. 65.00.

World Patent Information. International Journal for Patent Information and Documentation; a joint periodical of the Commission of the European Communities and the World Intellectual Property Organization. Vol. 1 no. 1-July 1979-München: K.G. Saur, 1979-Annual subscription: DM 58.00 .

Journal of Library Administration, Vol. 1, No. 1, January 1980, New York, Haworth Press, $\$ 36.00$ per year (USA), $\$ 46.00$ elsewhere.

This new journal is intended to be a working tool for library administrators and middle-management, and will deal with the broad array of new management theories, techniques, research, and application that can be utilized in the library and information service setting.

Subscriptions: Haworth Press, 149 Fifth Avenue, New York, New York 10010, USA.

\section{U.N. CHRONICLE}

To reduce expenses the United Nations has decided to publish its Chronicle quarterly rather than monthly. The U.N. switched to the new schedule after publishing four monthly issues in 1979. The July issue covers the events of April, May, and June.

From the point of view of international law research it is unfortunate that this useful reference source is curtailing the frequency of its appearance. It will now be much more difficult to keep up to date with the most recent developments in the United Nations. 


\section{NEW COMPARATIVE LAW JOURNAL}

The Union of Jurists' Associations of Yugoslavia and Yugoslavia's Institute of Comparative Law have commenced publication of a new journal in the French and English languages. The title of this new journal is Yugoslav Law/Droit Yougoslave. Frequency of publication and subscription price are not available.

The first issue, published in early 1979, contains short articles on Yugoslavian law as well as surveys of Yugoslavian legislation and court practice.

For information write to the Institute of Comparative Law, Terazije 41, Belgrad, Yugoslavia.

The Institute has also published a Guide to the Yugoslav Legal System available in English and French languages at the price of US\$12 or Dinars 200.

John A. Maher, "Supranational Regimes for Multinationals: The New Order with a New Farce?" 4 Delaware Journal of Corporate Law. 289-350 (1979).

In June 1976, the Organization for Economic Cooperation and Development (OECD) adopted a Declaration on International Investment and Multinational Enterprises which expressed criticism of the more invidious practices of discrimination against foreign investment and included Guidelines for Multinational Enterprises with a different emphasis toward international investment than such other documents as the United Nations Code of Conduct for Transnational Corporations. The author, a professor of law, analyzes the OECD declaration and compares it with other international endeavors to adjust the respective interests of developing countries and foreign investors, especially in the light of the new International Economic Order, proclaimed by the United Nations General Assembly in 1975 as its Resolution 3281. The article is extensively documented. It may therefore be of some interest to legal information and reference specialists.

\section{NEW PERIODICAL INDEX}

The cumulative 1951-1975 index to the Revew Critique de Droit International Privé has been published by Dalloz of Paris. Priced at FF 300 it contains 928 pages.

\section{New Journal: RESTAURATOR}

Despite its relatively high subscription cost, this new journal should be of interest to all libraries. It deals with the different aspects of col- 
lection, preservation and restoration of books. Articles in recent issues include such subjects as preservation of leather bookbinding, microbiodetioration of audiovisual materials, analysis of the aging of paper, and methods of preservation of paper. Edited by an international board, this journal is published on a quarterly basis by Munksgaard International Publishers, Ltd., Norre Sogade 35, DK-1370 Copenhagen K, Denmark. The subscription price for 1979 is Danish kr. 276 (or US\$55.20, £27.60, DM102.10).

Computer Networks: the International Journal of Distributed Informatique. Amsterdam, North-Holland Publishing Company.

The purpose of this special issue of "Computer Networks and Data Protection Law" is to give computer people an international overview of what has already happened in the data protection field, and how matters are likely to proceed in the foreseeable future. It is also designed to provide some insight to the underlying concepts of data protection, and the thought process and value of its practitioners.

Publisher: North-Holland Publishing Co., P.O. Box 103, 1000 AC Amsterdam, Netherlands.

\section{A NEW HUMAN RIGHTS PERIODICAL}

Human rights as a scholarly discipline abounds with periodicals, newsletters, and information services. Despite this abundance, new periodicals and services continue to emerge. The most recent arrival is Universal Human Rights: A Comparative and International Journal of the Social Sciences, Philosophy and Law.

Edited by Richard P. Claude, Professor of Government and Politics at the University of Maryland, this new journal is expected to be published quarterly by Earl M. Coleman Enterprises, Inc., P.O. Box 143, Pine Plains, New York 12567, U.S.A. (publishers of the Checklist of Human Rights Documents which is compiled at the Tarlton Law Library of the University of Texas). The subscription rate, in line with the unfortunate and misguided policy trend of too many scholarly publications, is discriminatory: US $\$ 19.50$ for individuals; US $\$ 39.50$ for libraries and other institutions.

\section{IALL CONFERENCE IN AUSTRALIA}

Rob Brian, Law Librarian at the University of New South Wales and Chairperson of the IALL Conference Organizing Committee in Australia, has published the following announcement in the Australian Law Librarians Group Newsletter, No. 32:

"It is proposed to hold an International Association of Law

Libraries Conference in Canberra in May 1981. Like other IALL 
courses this Conference would last four or five days and deal with Australia's legal system, legislation, law reports, legal research tools, and so on. Visits to law libraries would also be arranged. If such a Conference is to be a success we need to start planning now. Accordingly I would like to hear from colleagues interested in helping to plan the Conference. Please let me know whether you would like to give a paper or conduct a workshop session. I would also like to have an indication of who would be likely to attend.

Any ideas for an IALL Conference would be most welcome. Perhaps we should also include the legal materials, etc. of New Zealand and Papua New Guinea. Colleagues in those areas might let me know what they think." 


\author{
IALL \\ ANNUAL MEETING \\ AT \\ THE PHILIPPINE INTERNATIONAL \\ CONVENTION CENTER \\ (OFFICIAL LOCATION \\ OF THE IFLA \\ 46TH GENERAL CONFERENCE) \\ MaNila \\ Philippines \\ ON \\ Monday, August 18, 1980 \\ AT \\ 2:00 P.M. (14.00 Hours) \\ For further information contact: \\ IALL Headquarters \\ c/o Vanderbilt University \\ Law Library \\ Nashville, Tennessee 37203 U.S.A.
}

IALL members wishing to attend and participate in the other programs and social events of the IFLA Conference,

August 18-23, 1980, need to register with:

46th IFLA General Conference 1980

Philippine Library Associations, Inc.

Room 301

The National Library Building

P.O. Box 4118

Manila, Philippines 2801 